\title{
Globalization, Alienation and the Loss of Other-Wiseness
}

\author{
John O'Neill
}

\begin{abstract}
The author focuses on the impact of globalization on different aspects of civil society. He argues that the global division of labour, and the exodus of transnational corporations has resulted in a new configuration of the forces of integration and fragmentation of regional economies. Postmodernist emphasis on heterogeneity and uniqueness of cultural life has given the Radical Right justification for excluding attention to those considered as cultural minorities. Rather, we are reduced to a common denominator of economic strength as the only criterion of value and legitimacy.
\end{abstract}

\section{Précis}

Le point de mire de cet article est l'impact de la globalisation sur les différents aspects de la société civile. L'auteur développe une argumentation selon laquelle la division globale du travail et l'exode des entreprises supranationales aentraîné une fragmentation des économies régionales et une reconfiguration des forces d'intégrations. L'emphase postmoderniste mise sur le caractèreà la fois hétérogène et unitaire de la vie culturelle a fourni à la Droite Radicale des justifications pour marginaliser ceux que l'on considère comme faisant partie des minorités culturelles. Pire, nous en sommes réduits à considérer le dénominateur commun de la puissance économique comme le critère exclusif de toute valeur et de toute légitimité.

The modern state owes its distinctive form to the ways in which it answers to the articulation of an industrial society. In short, the polity, economy and sociocultural institutions of modern society have assumed particular

John O'Neill is Distinguished Research Professor Emeritus, Sociology, York University, Toronto. constellations at given stages of mercantile, industrial and post-industrial capitalism. ${ }^{1}$ Whenever these constellations of capitalism begin to shift, we are driven to examine their history or genealogy in order to estimate their probable path. To delimit the contesting discourses that emerge in a period of paradigm shift, we are obliged to take a stand on the base grammar of capitalism. Quite bluntly, as sociologists we cannot entertain the postmodern carnival of knowledge thrown up in the cultural sector of post-industrial capitalism, while in the economic and political sectors, the discourse of the market assumes an unalloyed hegemony in the rearticulation of our state and civic institutions. ${ }^{2}$ The globalized imperatives of the current stage of capitalism display none of the celebrated features of postmodernism-of subjectivity, of decentering, of pluralism, or of deconstructed racism and genderism. These are merely the ideological effects through which individuals misrecognize the evacuation of capital power from these very sites.

Where nothing is contested by capitalist interests, nothing is gained by identification with the fallout from the erasure and realignment of institutional relations demanded periodically by capitalist elites. If this were not so, we should have to believe that capitalist culture is a benignly self-analyzing culture either open to its consumers through the rhetoric of any of its commodities, or else intelligible to critics through its film, music, art and literature. On this view, Marx would have done better at a rock concert or a film festival than in the British Museum and Freud would have learned more in a sex shop than in analysis. But in fact the critical acclaim of Marx and Freud arises from that shift in cultural reflexivity we owe to their respective analyses of how we. appropriate capital and sexuality. We now see them as structures and histories of (un)consciousness that shape the grammar of our lives. From this critical perspective, every shift in the institutional forces of capitalism offers us an opportunity to deepen our ignorance of those forces. Indeed, our contemporary ignorance is guaranteed if we proliferate difference and drift despite the overwhelming global practice of mergers that narrow the rest of our practices.

The global division of labour, the exodus of transnational corporations whose decisions offset the nation state, has resulted in a new configuration of the forces of integration and fragmentation within and between regional economies. Yet, despite the celebrants of postmodern diverșity, it is precisely Euro-American culture that provides the dominant narrative of global capitalism. This is because global capitalism is still capitalism whose global consistency still generates contradictions, foreclosures and marginalization. The flexibility of global capital may well demand flexibility from its symbolic analysts but it just as certainly instills docility in its service-end producers. The much vaunted flexibility of postmodern culturalism either celebrates or else merely reflects its own subject-position within global capitalism. As I see it, the fragmentation of the Western canon is largely the product of franchising struggles between petty cultural capitalists striving to position themselves amidst the global restructuring of the knowledge, information and entertainment industries. The artful postmodern and deconstructionist practices of destabilizing the language of property, the proper, the lily-white, does not alter the system of inequality in which the discourse of property pervades every institution and level of everyday life in capitalist society. Moreover, the sites 
of these cultural tactics remain aloof from the majority of poor people, working poor and welfare poor.

\section{Class Not Culture}

Today, we are told by the New. Right that our civic covenant is an immoral and profligate exercise that can only be indulged by the nation state through the blindness of its politicians to the new world order. In an explosion of Darwinistic fervour, we are called to believe that a sudden shift in our economic environment has left every one of our social institutions obsolete-except for the market. Only by downsizing our moral and political baggage can we enjoy the proper release of that lean and mean individual energy that is demanded and rewarded by the market. In short, global capitalism remoralizes us by returning us to a state of nature from which it then draws us in accordance with the absolute law that our industry be ruled by a cognitive elite. To understand what institutional re-orientation is involved here, we need to remind ourselves of the social compact that is now under reconstruction-if not dismantling.

Production relations generate class relations and state/economy relations. Production is primary in the material sense but not necessarily politically. This is because the liberal state is presupposed in the dominance of industrial over mercantile and agrarian capitalism. The liberal state may also be engaged as an imperial nation-state on behalf of the mass production phase of capitalism in which class relations are harmonised through a national pact between business, labour and government:

A certain kind of political culture is, indeed, a condition for tripartism, one in which the state is regarded both as the instrument of civil society and at the same time as the agency for harmonizing civil society's divergent interests. Government is thought of both as the channel for procuring satisfaction for separate interests and as a force constraining these interests toward reconciliation. $^{3}$
Tripartism has, of course, never achieved perfect balance; any partner to the pact may be seen to dominate it.

With the globalization of production relations, we are perceiving the collapse of tripartism - the erosion of unionism, the hegemony of the market and the subordination of the redistributive welfare state that we siderable withdrawal of the legitimacy accorded to the neo-liberal welfare state, expressed in anti-state movements, tax revolts and new elite ideologies of self-interest and zero-altruism. These events, coupled with the severe polarization of incomes since the 1980s, put considerable strain upon civil society, caught between the

\section{As I see it, global capitalism has abandoned its potential for "other-wiseness" by absorbing all otherness into a single market of success and failure. By rejecting the corporatist contract between business, government and labour that has softened class differ- ences in the last half century, globalism now subjects everyone to the dominion of monetarism and the market, downsizing organizations and breaking unions.}

have known for the last fifty years. We can now see that the neo-liberal state was committed to growth rather than redistribution and to inflation as the price of tripartism. Inflation, however, when combined with the stagnation of the mid-1970s, began to erode the national income policies of tripartism. At the same time, the informal cooperation between the central agencies of government and the globalizing corporations was strengthened.

Finally, the conflict between the interests of international capital accumulation and the national welfare of vulnerable groups has come to a head. National governments are now subordinate to international finance institutions that enforce the new world order of production:

The state disengages from civil society-it reverses the trend toward interpenetration and blurring of the edges between state and society that corporatism promoted-in order to force more radically the adjustment of national economies to the world economy. 4

The result is that the civic capital expenditures of nation states are severely discounted, resulting in lower credit ratings, i.e. higher interest rates that further aggravate the national deficit. Yet, it is the welfare component of the deficit that is blamed for the overall effect. Currently, there is a con- anomic violence of marginalized groups and a generalized antipathy towards the elite composition of new scarcities and insecurities.

As I see it, global capitalism has abandoned its potential for "otherwiseness" by absorbing all otherness into a single market of success and failure. By rejecting the corporatist contract between business, government and labour that has softened class differences in the last half century, globalism now subjects everyone to the dominion of monetarism and the market, downsizing organizations and breaking unions. Worse still, the fragmentation of social citizenship is now accelerated by the New Right's curious adoption of left cultural relativism to announce that there are no objective moral principles to guide the pursuit of social justice:

Ideas of social justice and of basic needs, which form the threadbare clothing of contemporary social democratic movements, are of minimal help here. Criteria of desert and merit, such as enter into popular conceptions of social justice, are not objective or publicly corrigible, but rather express private judgments grounded in varying moral traditions. Conceptions of merit are not shared as a common moral inheritance, neutrally available to the inner city Moslem population of Birmingham and the secularized profes- 